\title{
Przemysław Kowalski
}

Uniwersytet w Białymstoku

e-mail: przemyslaw.ostroleka@gmail.com

\section{$\mathrm{Z}$ badań nad prawem spadkowym w projekcie kodeksu cywilnego z 1948 r.}

\author{
SUMMARY \\ Studies on the Law of Succession in the Draft Civil Code of 1948
}

After successful process of unification of Polish civil law in 1946, in the period 1947-1949 works on the codifications of this branch of law were held. In February 1947 the Codification Commission was established. The Commission was to prepare the version of Civil Code, based on the existing acts and decrees. The changes in the existing law could be done only exceptionally. The draft of inheritance law, as a part of civil code, was prepared by Seweryn Szer and Jan Witecki. The first reading was concluded in December 1948. There were some important changes in inheritance law, for example provisions concerning statutory scuccesion and - in particular, groups accepting succession. At last, the draft of inheritance law was not even published. In 1949 the work on new code was stopped beacuse of political reasons (the Stalinisation of Poland).

Key words: civil law, inheritance law, groups accepting succession, codifications, Codification Commission, stalinisation of Poland.

I.

Przeprowadzona w latach 1945-1946 unifikacja prawa cywilnego była, bez cienia wątpliwości, wielkim sukcesem nowej władzy¹. Jakkolwiek nie wzno-

1 Na marginesie wskazać należy, że przebieg uroczystej akademii podsumowującej dzieło unifikacji znany dotychczas był głównie z relacji w prasie prawniczej. Zob. zwłaszcza: Z okazji zakończenia unifikacji prawa cywilnego (akademia), DPP 1947, nr 1-2, s. 12-19. Podczas kwerendy, w ramach przygotowywania rozprawy doktorskiej dotyczącej dziejów prac nad kodyfikacją polskiego prawa cywilnego, w Narodowym Archiwum Cyfrowym udało mi się odnaleźć 43-minutowe nagranie radiowe tej uroczystości. Posłuchaj: Transmisja uroczystości poświęconej zakończeniu prac nad unifikacja prawa cywilnego w Polsce, odbywającej się w gmachu Prezydium Rady Ministrów w Warszawie (NAC, Zespół nagrań dźwiękowych 33-P-787). 
wiono prac Komisji Kodyfikacyjnej II Rzeczypospolitej, to owo dzieło nie byłoby możliwe bez sięgnięcia do jej dokonań. Ponadto, ze względu na szerokie oparcie na przygotowanych przed wybuchem II wojny światowej projektach, stanowiło de facto kontynuację prac przedwojennej Komisji².

Reforma prawa cywilnego zakończona w 1946 r., pomimo swojego szerokiego zakresu, nie miała charakteru kodyfikacji. Ta wymaga bowiem, co do zasady, jednego aktu legislacyjnego i oparcia całego systemu formalno-prawnego na konsekwentnie realizowanych założeniach ogólnych ${ }^{3}$.

Niemalże równocześnie z zakończeniem prac nad unifikacją ukazał się artykuł Jana Wasilkowskiego ${ }^{4}$. W tym tekście przedstawiony został program przyszłych prac kodyfikacyjnych. Autor uznał, że zakres prac powinien ograniczyć się jedynie do strony technicznej ustawodawstwa. Miały one mieć na celu wyłącznie wprowadzenie systematycznego układu materii, usunięcie błędów i sprzeczności, wypełnienie istotnych luk oraz nadanie poszczególnym tekstom jednolitej szaty zewnętrznej. Ewentualną zmianę norm zunifikowanego prawa dopuszczał tylko jako „zło konieczne"

Piotr Fiedorczyk zwrócił uwagę, że J. Wasilkowski nie zajął się zagadnieniem organizacji prac nad kodeksem cywilnym. Być może nawet on nie spodziewał się, że decyzja o podjęciu prac zapadnie tak szybko . Tymczasem minister H. Świątkowski wydał 18 lutego 1947 r. zarzadzenie o powołaniu komisji do spraw opracowania jednolitego polskiego kodeksu cywilnego ${ }^{7}$.

Decyzja o tak szybkiej kodyfikacji oznaczała, że a priori wykluczano dokonywanie szerzej pomyślanych zmian w zunifikowanym prawie. Zarządzenie ministra potwierdzało koncepcję J. Wasilkowskiego. Przewodniczenie Komisji powierzono ministrowi sprawiedliwości. Zastrzegł on sobie prawo wyznaczania zastępców spośród pracowników Ministerstwa. Zarządzenie wyznaczało stałych następców. Zostali nimi: Dyrektor Biura Ustawodawczego Stefan Bancerz, wicedyrektor tegoż Departamentu Seweryn Szer oraz Aleksander Wolter. Sekretarzem Komisji został sędzia Witold Czachórski. Jej członkami: Aleksander Wolter, Seweryn Szer, profesor Jan Wasilkowski oraz sędziowie Marian Lisiewski oraz Jan Witecki. Skład Komisji był tak skonstruowany, że tworzył

2 A. Lityński, Historia prawa Polski Ludowej, Warszawa 2010, s. 189.

3 W. Czachórski, Przebieg prac nad kodyfikacja prawa cywilnego PRL, „Studia Prawnicze” 1970, z. 26-27. Zeszyt specjalny wydany dla uczczenia pracy naukowej i kodyfikacyjnej Profesora Jana Wasilkowskiego, s. 8.

J. Wasilkowski, Zagadnienie kodyfikacji jednolitego prawa cywilnego, DPP 1947, nr 1-2, s. 62-64.

5 Ibidem, s. 62.

6 P. Fiedorczyk, O początkach prac nad kodyfikacja polskiego prawa cywilnego w 1947 r., MHI 2004, t. IV, s. 111-113.

7 Tekst za: idem, Dokumenty archiwalne dotyczace organizacji prac nad unifikacja i kodyfikacja polskiego prawa cywilnego w latach 1945-1948, MHI 2004, t. IV, s. 166. 
ją jeden przedstawiciel doktryny (J. Wasilkowski), dwóch sędziów Sądu Najwyższego (J. Witecki, M. Lisiewski) oraz dwóch pracowników Departamentu Ustawodawczego (S. Szer i A. Wolter, przy czym obaj związani byli także z sądownictwem). Pierwsze posiedzenie Komisji odbyło się 25 marca 1947 r. Otworzył je minister H. Świątkowski. Powtórzył konieczność oparcia projektu kodeksu na zunifikowanym prawie i kodeksie zobowiązań z 1933 r. Dopuścił jednak częściowe zmiany. Uznał, że prace powinny być zakończone w ciągu jednego roku. Następnie Komisja miała zająć się opracowaniem szczegółowych motywów projektu. Po tej wypowiedzi ministra H. Świątkowskiego Komisja rozstrzygnęła zagadnienia związane z zakresem prac i układem kodeksu. Uchwalono regulamin oraz wyznaczono referentów i koreferentów poszczególnych działów kodeksu. W toku dyskusji ustalono, że opracowanie projektu zostanie powierzone referentowi i koreferentowi. Wnosił o to J. Wasilkowski, przywołując doświadczenia Komisji Kodyfikacyjnej. Referent występował jako dominus projektu, koreferent zaś mu pomagał. Wprowadzano zasadę, że uchwały Komisji zapadać miały większością głosów. Komisja uchwaliła regulamin, który zatwierdzony został przez ministra H. Świątkowskiego 27 marca 1947 r. Przyznawał on szerokie uprawnienia właśnie ministrowi. Do ważności obrad potrzebna była obecność przynajmniej trzech członków. Projekt miał podlegać trzem czytaniom, do których należało sporządzić uzasadnienie. Konsultacje projektu ze środowiskiem prawniczym itp. miały odbyć się po I czytaniu8.

Przyjęto więc całkowicie odmienne rozwiązania organizacyjne niż przy procesie unifikacji prawa. Nadano pracom wyższą rangę. Objawiało się to chociażby w samym fakcie powołania Komisji oraz w sformalizowaniu jej prac. Warto pamiętać, że dzieło kodyfikacji powierzono tym samym osobom, które opracowały dekrety unifikacyjne. Praktycznie bez dyskusji ustalono, że na kodeks będzie składać się pięć ksiąg: część ogólna, prawo rodzinne, prawo spadkowe, prawo zobowiązań oraz prawo rzeczowe. Nie przesądzono kwestii kolejności poszczególnych ksiąg. Opracowanie tychże powierzono następującym członkom Komisji: J. Wasilkowski, A. Wolter - część ogólna, J. Witecki, S. Szer - prawo familijne, S. Szer, J. Witecki - prawo spadkowe, A. Wolter, M. Lisiewski - zobowiązania, M. Lisiewski, J. Wasilkowski - prawo rzeczowe9.

Prace Komisji przeciągnęły się na pewno do grudnia 1948 r. Ogłoszono na łamach „Demokratycznego Przeglądu Prawniczego" cztery księgi kodeksu. Projekty stały na dobrym poziomie. Odbyła się nad nimi dyskusja na łamach

8 Idem, O początkach..., s. 114-116.

9 Ibidem, s. 116-119. 
prasy prawniczej ${ }^{10}$. Łącznie opublikowano projekty, sprawozdania i artykuły w liczbie 32, dotyczące stricte materii kodyfikacyjnej. Dla porównania, projekt kodeksu cywilnego PRL z 1954 r. doczekał się już tylko 23 pozycji bibliograficznych $^{11}$.

Wskazać jednak należy, że projektu prawa spadkowego nie ogłoszono ${ }^{12}$. Więcej, prace nad tą księgą kodeksu cywilnego zostały ówcześnie całkowicie przemilczane ${ }^{13}$. Nie dziwił więc fakt „białej plamy” w tym przedmiocie. Ponadto prof. Adam Lityński w 2004 r. zwrócił uwagę na pewną prawidłowość, cechującą dotychczasowe badania nad prawem Polski Ludowej. Prawnicy badali niemal wyłącznie wymiar sprawiedliwości $w$ sprawach karnych (represje). Historycznoprawne badania innych gałęzi prawa były absolutnie unikatowe $^{14}$.

Dodatkowo podkreśla się, że prawo spadkowe od lat należy w Polsce do dyscyplin nieco zaniedbanych. Stąd też jego literatura, $\mathrm{w}$ porównaniu $\mathrm{z}$ innymi gałęziami prawa cywilnego, jest stosunkowo skromna. Profesor Bogudar Kordasiewicz wskazał podstawową, dość trywialną, przyczynę takiego stanu rzeczy. Prawo spadkowe nie może bowiem rozwijać się bez spadków. Nie może zatem dziwić, że w społeczeństwie, które po II wojnie światowej przez dziesiątki lat żyło biednie, nie było ekonomicznych warunków sprzyjających zainteresowaniu problematyką prawa spadkowego. W ciągu ostatniego półwiecza opublikowano zaledwie trzy rozprawy habilitacyjne ${ }^{15}$ oraz sześć prac doktorskich ${ }^{16}$.

10 A. Lityński, Nowe ustawodawstwo w nowym ustroju. O prawie karnym i cywilnym w pierwszym dwudziestoleciu Polski Ludowej, MHI 2006, t. IV, s. 134-135.

11 Z. Trybulski, Bibliografia prawa cywilnego. Literatura, orzecznictwo 1945-1954, Warszawa 1956, s. $111-115$.

12 S. Grzybowski, System prawa cywilnego. Część ogólna, Wrocław-Warszawa-Kraków-Gdańsk 1974, s. 39.

13 Celem ilustracji tego zjawiska można wskazać przykłady publikacji dwóch podstawowych autorów piszących o prawie spadkowym. Zarówno Jan Gwiazdomorski, jak i Józef Stanisław Piątowski płynnie przechodzili od dekretu prawo spadkowe do prac kodyfikacyjnych z lat pięćdziesiątych, nie wspominając, nawet wzmiankowo, o pracach nad prawem spadkowym w latach 1947-1949. Zob. J. Gwiazdomorski, Zarys prawa spadkowego, Warszawa 1961, s. 19; J. S. Piątowski, Prawo spadkowe. Zarys wykładu, Warszawa 1973, s. 19-23.

14 A. Lityński, Historia prawa Polski Ludowej, Warszawa 2004, s. 11-12.

15 E. Skowrońska, Forma testamentu w prawie polskim, Warszawa 1991; P. Księżak, Zachowek w polskim prawie spadkowym, Warszawa 2010; J. Wierciński, Brak świadomości albo swobody przy sporządzaniu testamentu, Warszawa 2010.

16 M. Kłos, Wspólność majątku spadkowego, Warszawa 2004; B. Kordasiewicz, Testamentowe dziedziczenie gospodarstw rolnych, Warszawa 1978; M. Niedośpiał, Testament w polskim prawie cywilnym - zagadnienia ogólne, Warszawa 1991; E. Niezbecka, Zapis, Lublin 1991; E. Skowrońska, Odpowiedzialność spadkobierców za długi spadkowe, Warszawa 1985; Z. Truszkiewicz, Zachowek ze spadku obejmującego gospodarstwo rolne, Kraków 1993. 
II.

Prace nad prawem spadkowym Komisja rozpoczęła 14 grudnia 1948 r., w przededniu wielkich wydarzeń politycznych ${ }^{17}$. W tym miejscu należy jednak cofnąć się do obrad z dnia 9 grudnia 1948 r. Wtedy to nastąpił „kopernikański przewrót" w sposobie prac Komisji.

Oczywiste jest, że sytuacja polityczna w grudniu 1948 r. nie sprzyjała pracom kodyfikacyjnym. Tym bardziej zaskakujące wydaje się powiększenie składu Komisji o dwóch nowych członków. Zostali nimi: Maurycy Grudziński (brat pisarza i więźnia łagrów i obozów NKWD, Gustawa Herlinga-Grudzińskiego) i Jerzy Marowski. Po raz pierwszy uczestniczyli w jej pracach właśnie 9 grudnia 1948 r. Zaakcentowano wówczas fakt, że nowi członkowie - sędziowie reprezentują Sąd Najwyższy.

Jednak nawet tak istotne wydarzenie nie było najważniejsze. Tego dnia Komisja obradowała nad zasadami ogólnymi prawa rzeczowego. Przed podjęciem ogólnej dyskusji głos zabrał J. Wasilkowski. Było to przełomowe wystąpienie. Stwierdził, że punktem wyjścia dotychczasowych prac było stanowisko, że jej zadaniem jest techniczne ulepszanie prawa obowiązującego. Jego meritum miało być poza dyskusją. Jednakże, zdaniem J. Wasilkowskiego, w obliczu przemian społeczno-politycznych, to stanowisko nie mogło być dalej podstawą prac nad prawem rzeczowym. Uzasadniał to tym, że pierwotny tok prac narażałby Komisję na ewentualny zarzut przejścia nad tymi przemianami do porządku dziennego. Stojąc na stanowisku, że obowiązkiem Komisji jest dać wyraz aktualnym potrzebom państwowym w pracach kodyfikacyjnych, zaproponował dwie metody pracy. Pierwszą było przystąpienie do głębokiej przebudowy obowiązującego prawa rzeczowego już w pierwszym projekcie księgi IV kodeksu. Drugą zaś pozostawienie szkieletu dotychczasowego prawa. Publikacja pierwszego projektu powinna być w takim przypadku poprzedzona słowem wstępnym. W nim Komisja miałaby przyznać, że ma świadomość potrzeby głębszej reformy. Jan Wasilkowski wypowiedział się za pierwszą z wymienionych metod. $W$ dyskusji poparli go S. Szer oraz dwaj nowi członkowie. Pozostała trójka przyłączyła się to tego poglądu ${ }^{18}$. Oznaczało to, że już wtedy odstąpiono od pierwotnych założeń kodyfikacyjnych.

17 Protokót z posiedzenia Komisji Kodyfikacyjnej Prawa Cywilnego z dnia 14 grudnia 1948 r. (AAN MS 2381, k. 166).

18 Protokót posiedzenia Komisji Kodyfikacyjnej Prawa Cywilnego w dniu 9 grudnia 1948 r. w Kamionkowie (AAN MS 2381, k. 102-103). 


\section{III.}

Mając na uwadze zarówno ww. uchwałę, jak i pierwotne założenia postawione Komisji, podkreślić trzeba zwłaszcza jedną zmianę w przedstawionym Komisji projekcie prawa spadkowego. Artykuł 16 projektu $^{19}$, w porównaniu z dekretem różnił się jednym, ale zasadniczym, słowem. Referent, wychodząc zdecydowanie poza założenia, ograniczył bowiem krąg spadkobierców w linii bocznej do dzieci rodzeństwa. Przypomnijmy, w dekrecie mowa była o zstępnych rodzeństwa.

Jakkolwiek Komisja zdawała sobie sprawę z sytuacji politycznej, to już przebieg pierwszego dnia obrad wskazuje, że antycypowanie zmian w prawie sprawiało jeszcze jej członkom pewne problemy. Najżywszą część obrad poświęcono bowiem kwestii dziedziczenia przez fundacje. Projekt nie przewidywał zmian rozwiązań dekretowych. Tymczasem, po kilku propozycjach zmian, przegłosowano wniosek J. Marowskiego. Przedłużono w ten sposób roczny termin, przewidziany dla utworzenia fundacji powołanej $\mathrm{w}$ testamencie, do lat trzech. Termin liczyć należałoby od otwarcia testamentu ${ }^{20}$. Biorąc pod uwagę, co do zasady, zniesienie fundacji dekretem z dnia 24 kwietnia 1952 r. ${ }^{21}$, dyskusja była (niestety) bezprzedmiotowa.

Prace kontynuowano dnia następnego. Przed przystąpieniem do właściwych obrad, S. Szer nawiązał do rozpoczynających się w Warszawie obrad Kongresu Polskiej Partii Robotniczej i Polskiej Partii Socjalistycznej. Podkreślił „historyczną doniosłość zjednoczenia się obu tych Partii, która stanie się gwarancją dobrobytu gospodarczego, siły politycznej i rozwoju kulturalnego Polski" 22. Cytat ten doskonale wprowadza w, niewątpliwie towarzyszącą pracom, duszną atmosferę.

Podkreślić trzeba kolejne zmiany przepisów dekretowych, które wprowadzono odnośnie do niegodności dziedziczenia. Po wniosku J. Marowskiego, popartego przez A. Woltera, zgodnie przyjęto, że nakłonienie podstępem lub groźbą do zmiany testamentu przestało być przesłanką niegodności ${ }^{23}$. Wskazać należy, że takie właśnie rozwiązanie znalazło się w przepisie art. 928 § 1 pkt 2 kodeksu cywilnego ${ }^{24}$ z 1964 r. Przepis art. 9 projektu ${ }^{25}$ regulował z kolei kwestię przebaczenia przez spadkodawcę. Jan Wasilkowski stwierdził, że na-

19 Art. 16 projektu: „Spadkobiercami ustawowymi z tytułu pokrewieństwa są krewni spadkodawcy: w linii zstępnej - bez ograniczenia, w linii wstępnej - tylko rodzice, w linii bocznej - rodzeństwo i jego dzieci". Tekst projektu cyt. dalej w pracy za: AAN MS 2181, k. 34-76.

20 Protokót z posiedzenia Komisji Kodyfikacyjnej Prawa Cywilnego z dnia 14 grudnia 1948 r. (AAN MS 2381, k. 169).

21 Dz. U. 1952 Nr 21, poz. 97.

22 Dalszy ciag posiedzenia Komisji w dniu 15 grudnia 1948 r. (AAN MS 2381, k. 169-170).

23 Ibidem, k. 170.

24 Dz. U. 1964 Nr 16, poz. 93. 
leży zdawać sobie sprawę z tego, jakie znaczenie ma mieć niegodność w prawie polskim. Prawo francuskie uznawało, iż przepisy o niegodności dążą do ochrony interesu publicznego. Ten punkt widzenia był jego zdaniem słuszny. W konsekwencji prowadził bowiem do wykluczenia możności uchylenia niegodności przez przebaczenie ze strony spadkodawcy. Ewentualnie rozważał dopuszczenie jednego wyjątku. Wówczas, gdy spadkodawca wyraźnie powołałby spadkobiercę do spadku w testamencie sporządzonym po ujawnieniu przyczyny niegodności. Redakcji przepisu art. 9 zarzucił, że przepis ten ma być przepisem interpretacyjnym. Dodał, że taka konstrukcja wydaje się wadliwa. Jerzy Marowski poparł pogląd J. Wasilkowskiego. Dodatkowo stwierdził, iż rozwiązanie analogiczne do propozycji J. Wasilkowskiego znajdowało się w projekcie prawa cywilnego radzieckiego. Jan Witecki wypowiedział się z kolei za dopuszczeniem przebaczenia również i poza testamentem. Aleksander Wolter i Marian Lisiewski wypowiedzieli się za drugą tezą. W głosowaniu wniosek J. Wasilkowskiego uzyskał 4 głosy przeciwko 3. Ograniczono więc możliwość przebaczenia w sposób radykalny ${ }^{26}$. Był to z pewnością krok w ,jedynie słusznym kierunku".

Część obrad dotycząca dziedziczenia ustawowego potwierdziła, że pierwotne założenia prac kodyfikacyjnych to już przeszłość. Krąg spadkobierców ograniczono, jak wskazano wyżej, już na etapie projektu. Takie rozwiązanie za niewystarczające uznał jednak J. Wasilkowski. Zgłosił dwa wnioski. W ramach pierwszego chciał ograniczyć krąg spadkobierców ustawowych w linii bocznej tylko do rodzeństwa. W ramach drugiego rozszerzyć krąg tych spadkobierców na osoby niezdolne do pracy, które w chwili śmierci spadkodawcy pozostawały co najmniej od roku na jego utrzymaniu. Ewentualnie osobom, o których mowa, proponował przyznać alimentację zamiast udziału w spadku. Rozgorzała dyskusja. Do wniosku pierwszego J. Marowski wyraził pogląd, że wniosek J. Wasilkowskiego był niekonsekwentny, również jak i proponowany przepis art. 16 projektu. Dodał, że należy przyjąć albo rozwiązanie prawa obowiązującego, które dopuszcza do dziedziczenia rodzeństwo i jego zstępnych bez ograniczeń, a więc nie tylko dzieci rodzeństwa, albo postanowić, iż w ogóle krewni boczni a więc rodzeństwo - nie dziedziczą. Rozwiązanie proponowane przez J. Wasilkowskiego krzywdziło jego zdaniem nieletnich w przypadku, gdy np. z trojga rodzeństwa, które byłoby powołane do spadku - jedno nie żyje, lecz pozostawiło nieletnie dzieci. Aleksander Wolter poparł całkowicie pogląd J. Marowskiego. Po dyskusji - w głosowaniu wniosek J. Wasilkowskiego uzyskał 4 głosy. Jak głosowano w tej fundamentalnej kwestii? Jan Wasilkowski, S. Szer,

25 Art. 9 projektu: „Niegodny może dziedziczyć, jeżeli mu spadkodawca przebaczył. Przebaczenie ma być wyraźne lub dorozumiane. W szczególności uważa się, że spadkodawca przebaczył niegodnemu, jeżeli mając przyczynę niegodności powołuje go do spadku".

26 Dalszy..., k. 171. 
M. Grudziński i J. Witecki „za”. Przeciwko byli A. Wolter i M. Lisiewski. Jerzy Marowski, który merytorycznie podważał zasadność wniosku J. Wasilkowskiego, tylko wstrzymał się od głosu. To głosowanie okazało się dość reprezentacyjne dla następnych kwestii spornych. Co ciekawe, nawet jeśli Komisja nie zostałaby powiększona o dwóch nowych członków, rezultat głosowania byłby identyczny. Do wniosku drugiego M. Grudziński uważał, że nie jest wskazane dalsze powiększanie kręgu spadkobierców. Tym bardziej, jeśli krąg ten ograniczono stosownie do pierwszego wniosku J. Wasilkowskiego. Jerzy Marowski zapytał, czy nie należałoby przewidzieć dla osób objętych wnioskiem użytkowania części majątku spadkodawcy. Jan Wasilkowski wypowiedział się przeciwko tej koncepcji. Zagadnienie wysokości udziałów osób objętych wnioskiem drugim w zbiegu ze spadkobiercami ustawowymi, miało być rozważone po przesądzeniu samej zasady. W głosowaniu drugi wniosek J. Wasilkowskiego upadł. Oprócz wnioskodawcy poparł go tylko S. Szer²7.

Komentując kwestię rodzeństwa, nasuwa się analogia do rozwiązań radzieckich $^{28}$. Nie można jednak zapomnieć, że podobna, aczkolwiek nie tak radykalna tendencja, charakteryzowała również ówczesne prawo państw europejskich, niebędących satelitami ZSRR. Już w pracach Komisji Kodyfikacyjnej II RP wskazać można na ten trend ${ }^{29}$. Również podczas prac nad dekretem dotyczącym prawa spadkowego postanowiono, na tle obowiązujących przepisów zaborczych, ograniczyć krąg spadkobierców ${ }^{30}$. Sprawa dziedziczenia zstępnych rodzeństwa była następnie przedmiotem rozważań w trakcie prac nad kolejnymi projektami kodeksu cywilnego ${ }^{31}$.

Kwestia dziedziczenia dzieci pozamałżeńskich była kolejnym sprawdzianem dla Komisji. W art. 20 projektu ${ }^{32}$ referent zmienił analogiczny przepis dekretu. Jan Witecki wniósł o skreślenie tej zmiany w § 1 (dodanie słów: "oraz którego ojcostwo nie zostało ustalone"). Zaproponował powrót do tekstu

27 Ibidem, k. 174-176.

28 A. Lityński, Prawo Rosji i ZSRR 1917-1991 czyli historia wszechzwiązkowego komunistycznego prawa (bolszewików). Krótki kurs, Warszawa 2010, s. 239-246.

29 L. Górnicki, Prawo cywilne w pracach Komisji Kodyfikacyjnej Rzeczypospolitej Polskiej w latach 1918-1939, Wrocław 2000, s. 269-311.

30 Dodatkowo, na tle ustaleń poczynionych przez Aleksandrę Kozioł wydaje się, że np. J. Gwiazdomorski, inspirowany S. Wróblewskim, rozważał ograniczenie kręgu spadkobierców do rodzeństwa. Z kolei Z. Wasilkowska chciała ograniczyć spadkobranie do dzieci rodzeństwa. Zob. A. Kozioł, Prace nad unifikacja prawa cywilnego w Polsce w latach 1945-1946 (Maszynopis rozprawy doktorskiej napisanej i obronionej na Wydziale Prawa i Administracji UŚ pod kierunkiem prof. A. Lityńskiego), Katowice 2006, s. 115-116, 121. Za jego udostępnienie serdecznie dziękuję P. Dr. P. Fiedorczykowi.

31 M. Kuryłowicz, Krąg spadkobierców ustawowych w ujęciu prawnohistorycznym, „Rejent” listopad 2006, nr 13 , s. 28.

32 Art. 20 projektu: „§ 1. Dziecko pozamałżeńskie, które nie zostało uprawnione, uznane albo zrównane oraz którego ojcostwo nie zostało ustalone, dziedziczy tylko po swej matce i jej rodzinie. $\S 2$. Po dziecku takim, w braku zstępnych, dziedziczy tylko jego matka i jej rodzina". 
prawa obowiązującego (art. 20 dekretu). Ewentualnie wniósł o zmianę redakcji projektu - jak we wnioskach drukowanych współreferenta. Po raz kolejny referent zmienił więc $\mathrm{w}$ sposób istotny treść dekretu. Rozgorzała dyskusja. Rozpoczął A. Wolter. Uważał, że należy przesądzić przede wszystkim samą zasadę prawną. Zwrócił uwagę, że rozszerzenie uprawnień dzieci pozamałżeńskich nieuprawnionych (uznanych lub zrównanych) na prawo spadkowe było sprzeczne $\mathrm{z}$ uchwalonymi zasadami i tendencją projektu prawa rodzinnego. Seweryn Szer wyjaśnił, iż rozszerzenie uprawnień dzieci pozamałżeńskich jest stałym postulatem organizacji kobiecych. Jerzy Marowski poparł ten postulat. Dodał, że projekt prawa rodzinnego ulegnie zmianie. Profesor J. Wasilkowski zgadzał się z tym stanowiskiem. Skoro kogoś obciążono ojcostwem w wyroku sądowym - to przyznanie dziecku praw spadkowych było tylko dalszą konsekwencją tego stanowiska. Konsekwencją i tak mniej dotkliwą dla ojca niż świadczenia, które musiał ponieść za swego życia. Nie zgodził się z tym M. Grudziński. Uważał, że trzeba zdawać sobie sprawę z tego, że zasada ta osłabia znaczenie legalnej rodziny. Aleksander Wolter był zaś zdania, że wprowadzenie tych daleko idących konsekwencji ojcostwa $\mathrm{z}$ wyroku sądowego nie może nie odbić się na stanowisku sądów. Miałyby one ostrzej kwalifikować przesłanki przemawiające za wydaniem wyroku na korzyść dziecka. Jan Witecki wypowiedział się przeciwko zmianie. W głosowaniu zasada wprowadzona przez S. Szera do przepisu art. 20 projektu uzyskała 4 głosy przeciwko 3 (M. Lisiewski, A. Wolter, J. Witecki). Na tle tego głosowania A. Wolter stwierdził, że w konsekwencji trzeba poddać rewizji przepisy projektu księgi II (prawo rodzinne) ${ }^{33}$. Znamienne jest to, że $\mathrm{w}$ dyskusji nie podniesiono kwestii pełnego zrównania dzieci pozamałżeńskich. Tymczasem, niespełna rok później, na mocy przepisów wprowadzających kodeks rodzinny z $1950 \mathrm{rr}^{34}$, ze względu na pełne zrównanie dzieci, uchylono wyżej omówiony przepis dekretu.

Odnośnie do dziedziczenia małżonka warto wspomnieć o przepisie art. 22 projektu ${ }^{35}$. Było to powielenie rozwiązania dekretowego. Na tym tle bardzo ciekawą propozycję wyartykułował A. Wolter. Wniósł on o wprowadzenie zasady, że małżonek wyłącza rodzeństwo przy dziedziczeniu ustawowym. Wniosek upadł (2 głosy przeciwko 5) ${ }^{36}$. Zwraca uwagę, że zasada ta została wprowadzona do kodeksu cywilnego w 2009 r. ${ }^{37}$

33 Dalszy..., k. 176-178.

34 Dz. U. 1950 Nr 34, poz. 309.

35 Art. 22 projektu w wersji pierwotnej: „Pozostały przy życiu małżonek dziedziczy z ustawy: w zbiegu ze zstępnymi małżonka zmarłego - jedną czwartą część spadku, w zbiegu z jego rodzicami i rodzeństwem lub zstępnymi rodzeństwa - połowę spadku, a w braku takich krewnych cały spadek". Na egzemplarzu z naniesionymi ołówkiem poprawkami, „zstępni rodzeństwa” byli już wykreśleni.

36 Dalszy..., k. 180.

37 Ustawa z dnia 2 kwietnia 2009 r. o zmianie ustawy - Kodeks cywilny (Dz. U. 2009 Nr 79, poz. 662). 
IV.

Bodaj najbardziej interesującą częścią obrad była jednak kwestia zachowku. Na początek wskazać trzeba, że projektowany krąg osób uprawnionych do zachowku był powtórzeniem rozwiązań dekretowych ${ }^{38}$. Nie spotkało się to z aprobatą J. Witeckiego. Wniósł on bowiem o skreślenie rodziców spadkodawcy z liczby osób uprawnionych do zachowku. Jan Wasilkowski wypowiedział się przeciwko tej zmianie. W głosowaniu wniosek J. Witeckiego upadł (1 głos) $)^{39}$. Przesłanki wydziedziczenia były identyczne z dekretowymi. Jan Wasilkowski uważał, że przyczyny wydziedziczenia ujęte były zbyt wąsko. Zastrzegł sobie możliwość zgłaszania kolejnych wniosków w tej kwestii ${ }^{40}$. Żaden z członków Komisji nie wypowiedział się na temat zagadnienia dopuszczalności wydziedziczenia częściowego ${ }^{41}$. Wydaje się więc, że cała Komisja podzielała zdanie J. Witeckiego co do niedopuszczalności wydziedziczenia częściowego ${ }^{42}$.

Jeśli chodzi o przepis art. 136 projektu ${ }^{43}$, to A. Wolter stwierdził, iż projekt referenta pomijał zdanie 1 art. 151 dekretu. W dekrecie uregulowano, jak ustalać zachowek dla spadkobierców koniecznych (połowa wartości przy dziedziczeniu ustawowym). W projekcie pierwszy art. dotyczący tej kwestii zmieniał ustalenie wartości zachowku dla dzieci małoletnich z połowy na całość wartości przy dziedziczeniu ustawowym. Aleksander Wolter uznał, że przepis dekretu powinien być przywrócony. Jan Wasilkowski podtrzymał tezę projektu referenta, iż powinno istnieć rozróżnienie co do wysokości zachowku dzieci małoletnich w stosunku do pozostałych uprawnionych. Argumentował, że teza ta znana była prawu francuskiemu i szwajcarskiemu. Wniósł jeszcze o rozszerzenie zasady dotyczącej dzieci małoletnich również na osoby niezdolne do pracy. Jerzy Marowski wypowiedział się przeciwko powiększeniu

38 Przepis art. 129 projektu: „Spadkobiercami koniecznymi to jest osobami uprawnionymi do zachowku są zstępni, rodzice oraz małżonek spadkodawcy, jeżeli osoby te w chwili otwarcia spadku dziedziczą po nim jako spadkobiercy ustawowi lub dziedziczyliby w braku testamentu ustanawiającego spadkobierców".

39 Dalszy..., k. 221-222.

40 Ibidem, k. 222.

41 O doktrynalnych kontrowersjach odnośnie do tego zagadnienia zob. B. Kordasiewicz, Krąg osób uprawnionych do zachowku, [w:] Księga jubileuszowa Profesora Tadeusza Smyczyńskiego, red. M. Andrzejewski i in., Torun 2008, s. 420-422; M. Załucki, Wydziedziczenie w prawie polskim na tle porównawczym, Warszawa 2010, s. 82-84.

42 J. Witecki, Odpowiedź na pytanie prawne, PiP 1949, nr 2, s. 109-110.

43 Art. 136 projektu: „Wartość zachowku dzieci małoletnich spadkodawcy wynosi wartość udziału, jaki spadkobierca konieczny otrzymałby przy dziedziczeniu ustawowym, przyjmując za podstawę obliczenia wartości spadku, ustaloną według przepisów niniejszego rozdziału. Wartość zachowku zstępnych pełnoletnich spadkodawcy, jak również pozostałych spadkobierców koniecznych wynosi połowę wartości wspomnianego udziału". 
zachowku małoletnich. Co innego zachowek osób niezdolnych do pracy. Jan Witecki wyraził pogląd, iż wniosek S. Szera doprowadzi do zbędnych komplikacji, zwłaszcza przy powrotach. Aleksander Wolter uważał, iż w ówczesnym ustroju społeczno-gospodarczym Polski teza Szer-Wasilkowski była nietrafna. Przy dziedziczeniu takich obiektów gospodarczych jak warsztat rzemieślniczy, grunt, nieruchomość miejska - różnica w prawach małoletniego w stosunku do pełnoletniego nie miała uzasadnienia. Co do osób niezdolnych do pracy to wyróżnienie ich $\mathrm{w}$ przepisach o zachowku było teorią. $\mathrm{W}$ praktyce rodzice nigdy nie krzywdzili dzieci niezdolnych do pracy. Profesor J. Wasilkowski uważał, że argumenty A. Woltera są przekonywające. Poparł powrót do stanowiska prawa obowiązującego. Przyjęto zgodnie w miejsce przepisu art. 136 projektu zasadę art. 151 dekretu, tj. brak odróżnienia między uprawnionymi do zachowku w jednej i tej samej klasie ${ }^{44}$.

To jednak nie był koniec wątpliwości na tle przepisu art. 136 projektu. Jan Wasilkowski zgłosił wniosek, aby wysokość zachowku zstępnych była zależna od ich liczby. Mianowicie: jedno dziecko $-1 / 2$ udziału ab intestato, gdy dwoje dzieci - 2/3 udziału ab intestato, gdy troje dzieci lub więcej - 3/4 udziału ab intestato. Wysokość udziału małżonka i rodziców winna wynosić zawsze $1 / 2$ udziału ab intestato. W dekrecie nie było tego rodzaju rozróżnienia. Jerzy Marowski uważał, że podwyższenie ułamków zachowku jest nieuzasadnione przy systemie, w którym zachowek jest prawem obligacyjnym. Uważał natomiast, iż podwyższenie ułamków byłoby uzasadnione, gdyby przejść na system rezerwy; miałoby ono wówczas znaczenie jako zmierzające do walki z kułactwem na wsi. Jan Wasilkowski wyraził pogląd, iż właściwie już obciążenie spadkobiercy utrzymującego się przy spadku zachowkiem w wysokości $1 / 2$ udziału ab intestato na rzecz spadkobierców ustawowych było niesłychanie uciążliwe. Wymagało specjalnego systemu kredytów państwowych na spłaty spadkowe - jak to było przyjęte np. w Szwajcarii, a następnie i w Niemczech. Poza tym obciążenie spadkobiercy utrzymującego się przy spadku spłatą zachowku było w praktyce ułatwiane przez to, iż nisko szacowało się jego spadek. Różnica szacunkowa np. nieruchomości osobowych według BGB wynosiła dużą sumę. Tam nieruchomości szacowało się według wartości dochodowej, a nie sprzedażnej. Stosunek tych wartości wynosił 70/100 w Polsce. Co oczywiste, nie można było się liczyć z uruchomieniem kredytów publicznych na spłaty spadkowe. W konkluzji J. Wasilkowski zgłosił wniosek o przejście na system rezerwy.

Aleksander Wolter wyraził pogląd, iż nie można sprawy odstąpienia przy zachowku od legis latae rozważyć tylko od strony wpływu, jaki będzie wywierać na nieruchomości wiejskie. Zachowek jako obligacja był najbardziej 
celowy przy spadkobraniu takich dóbr gospodarczych jak warsztaty rzemieślnicze, warsztaty drobnego przemysłu itp. Dodał, że zagadnienie walki z kułactwem na wsi może być przedmiotem odrębnych przepisów poza kodeksem. Co ciekawe, S. Szer wypowiedział się za utrzymaniem systemu prawa obowiązującego z tym, aby sprawę ewentualnego przejścia na rezerwę pozostawić do II czytania. Jerzy Marowski poparł wniosek J. Wasilkowskiego o zmianę systemu dotychczasowego na system rezerwy. W głosowaniu wniosek J. Wasilkowskiego jednak nie uzyskał większości (3 głosy przeciwko 3 - J. Witecki, M. Lisiewski, A. Wolter). Wniosek J. Wasilkowskiego o zmianę ułamków na gruncie systemu prawa obowiązującego również upadł (3 głosy przeciwko 3 - A. Wolter, M. Lisiewski, J. Marowski) ${ }^{45}$.

Odnosząc się do tych problemów, nie można pominąć kilku kwestii. Znane jest stanowisko S. Szera na temat zachowku. Przedstawił je bowiem w artykule opublikowanym niespełna rok po opisywanych obradach: „Jest rzeczą oczywistą, że zachowek jako wyraz wspomnianej tendencji burżuazyjnego prawa, jest nie do utrzymania w przyszłym polskim prawie spadkowym. Jeżeli jego celem jest zabezpieczenie słusznych interesów najbliższej rodziny, jeżeli ma służyć umocnieniu tej rodziny w Państwie Ludowym, jeżeli ma chronić rozszerzającą się $\mathrm{w}$ wyniku dokonujących się $\mathrm{u}$ nas przemian własność osobistą $\mathrm{w}$ oparciu o własność socjalistyczną, to jedynie właściwą jest rezerwa, oparta na zasadzie sprawiedliwego traktowania wszystkich spadkobierców. System rezerwy przyjmuje prawo radzieckie i prawo spadkowe bułgarskie" 46 . Zwraca więc uwagę wcześniejsza powściągliwość $\mathrm{w}$ tej materii, zaprezentowana $\mathrm{w}$ trakcie grudniowych obrad.

Z kolei na tle tej propozycji J. Wasilkowskiego, tym bardziej nie dziwi fakt, że projekty z lat 1954, 1955, 1960 przewidywały system rezerwy, mimo zachowania nazwy ",zachowek" ${ }^{47}$. Postulat de lege ferenda odnośnie do wprowadzenia systemu rezerwy został sformułowany także, w innych realiach politycznych, $\mathrm{w}$ okresie międzywojennym ${ }^{48}$. Na tle wypowiedzi doktryny, formułowanych w latach pięćdziesiątych, zwracają zaś uwagę pozbawione argumentacji politycznej, wyważone artykuły z lat czterdziestych, odnoszące się do rozwiązań dekretowych ${ }^{49}$.

45 Dalszy ciag posiedzenia Komisji w dniu 19 grudnia 1948 r. (AAN MS 2381, k. 225-227).

S. Szer, Z zagadnień kodyfikacji prawa spadkowego, PiP 1951, z. 1, s. 923-924.

47 P. Księżak, op. cit., s. 44.

48 Najdobitniej wyraził to Kazimierz Przybyłowski w słynnym artykule opublikowanym tuż przed wybuchem II wojny światowej. Zob. K. Przybyłowski, Rezerwa czy zachowek?, GSW z 22 maja 1939 r., nr 21, s. 289-292.

49 Tytułem przykładu: Projekt prawa spadkowego. Tezy społeczno-polityczne, DPP 1946, nr 3, s. 72. 
V.

O ile bardzo trudno jest napisać cokolwiek pozytywnego o początkach Polski Ludowej, to jednak akcja unifikacyjna wyłamuje się z tego negatywnego schematu. O jej doniosłości i wysokim poziomie niech świadczy fakt, że w zakresie prawa spadkowego, co do zasady, do dziś utrzymano większość konstrukcji. W panującym po wojnie gigantycznym chaosie kwestia uregulowania tej dziedziny była niezbędna. Można jeszcze przekornie dodać, że wśród wielu pozytywnych cech unifikacji należy też wskazać jedną, która jak wydaje się, przypadła do gustu towarzyszom radzieckim. Mianowicie do 31 grudnia 1946 r., na niewielkim terenie satelickiego państwa ZSRR, nadal obowiązywało przecież carskie ustawodawstwo.

Podjęte, niemalże od razu po zakończeniu unifikacji, prace nad kodyfikacją miały bardzo ciekawy przebieg. Trzeba pamiętać, że początkowo kodyfikacja miała być ograniczona tylko do spraw technicznych, językowych i redakcyjnych. Rację miał P. Fiedorczyk, wyrażając wątpliwość co do przebiegu tych prac. Adiuvare często bowiem staje się fikcją w zetknięciu z rzeczywistością50. Z tego zdała sobie sprawę również Komisja. Już w grudniu 1948 r. postanowiono porzucić pierwotne założenia i zacząć zmieniać prawo na „Nowe”. Inicjatorem takiej uchwały był J. Wasilkowski. W słynnej samokrytyce, jaką złożył w 1950 r. na piśmie ${ }^{51}$, de facto powtórzył wnioski ww. uchwały.

Odnalezienie w Archiwum Akt Nowych projektu księgi V prawa spadkowego, stworzonego na podstawie grudniowych uchwał Komisji, było sporym zaskoczeniem. Tym bardziej, że projekt został przez J. Witeckiego nadesłany dopiero w marcu 1949 r. W liście do W. Czachórskiego podkreślał on, że trzymał się ściśle uchwał Komisji. Jednocześnie przepraszał za styl, w jakim sporządził tekst ${ }^{52}$, własnoręcznie, $\mathrm{z}$ wieloma skreśleniami i poprawkami. Tłumaczył to pośpiechem i chorobą. Jednocześnie prosił o poinformowanie go o dacie następnego posiedzenia Komisji ${ }^{53}$.

Obrady nad prawem spadkowym przebiegały równolegle z powstawaniem PZPR na słynnym kongresie „zjednoczeniowym”. Jak wiadomo, na sierpniowo-wrześniowym plenum KC PPR „zdemaskowano i zlikwidowano odchylenie prawicowo-nacjonalistyczne w partii". Odsunięto od władzy ekipę Władysława Gomułki. Ster rządów objęła ekipa Bolesława Bieruta. Nastąpiła przyspieszona stalinizacja wszystkich sfer życia społecznego. To samo musiało dotyczyć również kodyfikacji prawa cywilnego ${ }^{54}$.

\footnotetext{
50 P. Fiedorczyk, O początkach..., s. 120.

51 J. Wasilkowski, Kodyfikacja prawa cywilnego w Polsce, NP 1950, nr 12, s. 4.

52 Księga V. Prawo spadkowe (AAN MS 2181, k. 3-33).

53 List Jana Witeckiego z dnia 2 marca 1949 r. (AAN MS 2181, k. 2).

54 A. Lityński, Historia..., s. 202.
} 
Wiceminister sprawiedliwości Leon Chajn, jakkolwiek entuzjasta unifikacji, już dwa lata przed tymi wydarzeniami ostrzegał środowisko prawnicze: „W prawnictwie polskim, gdzie głębokimi korzeniami tkwi i tradycja i przyzwyczajenia i sentyment dla starych norm, postawa rozterki, postawa trwania na pozycjach wewnętrznej emigracji, postawa poważnego życzenia odwracalności dokonanych zmian, ukrywana za parawanem wyczekiwania na normalizację - jest źródłem częstych nieporozumień i zadrażnień" 55 .

Sam minister H. Świątkowski apelował: „Poznajmy prawo radzieckie”56.

O tym wszystkim przypominał członkom Komisji S. Szer. On jako referent projektu księgi V przyszłego kodeksu w porównaniu z dekretem wprowadził pewne zmiany. Nie były one jednak bardzo radykalne. Ograniczył co prawda krąg spadkobierców (zamiast wstępnych rodzeństwa dziedziczyć miały dzieci rodzeństwa). Dalej jednak utrzymano ograniczenie praw dzieci pozamałżeńskich. Przetrwał zachowek, a wręcz rozbudowano przepisy normujące tę materię.

Pochodzące z 1946 r. polskie prawo spadkowe nie różniło się w sposób istotny od praw spadkowych państw kapitalistycznych ${ }^{57}$. Ze względu na brak radykalnych zmian $\mathrm{w}$ opisanych wyżej pracach, należy podtrzymać, ówcześnie dyskwalifikującą, opinię. W piśmiennictwie podkreślono, że przerwanie w 1949 r. prac nad pierwszym polskim kodeksem cywilnym, opartym na zunifikowanym prawie, stanowiło niewątpliwie cios dla polskiej myśli prawniczej ${ }^{58}$. Oczywiście należy sobie zdawać sprawę, że prawo spadkowe nie było największym problemem w nowych realiach. Podstawowym „zagrożeniem” było prawo rzeczowe, własność.

Uchwalony w I czytaniu kodeks potraktowano jako anachronizm już w momencie powstania. Uznano, że prawo zunifikowane $\mathrm{w}$ znacznej części się zdezaktualizowało. Nie pasowało do modelu zetatyzowanej, nakazowej gospodarki ${ }^{59}$. Podstawowym zarzutem było jego burżuazyjne pochodzenie. Tymczasem Polska Ludowa wchodziła już otwarcie w okres stalinizacji. Świetnie ujął zaś to Poeta właśnie w 1949 r., następującymi słowami ${ }^{60}$ :

55 L. Chajn, O wtaściwe rozeznanie. Na marginesie trzeciej rocznicy manifestu PKWN, DPP 1947, nr 7, s. 3.

56 H. Świątkowski, Poznajmy prawo radzieckie, DPP 1948, nr 11, s. 4.

57 J. Gwiazdomorski, op. cit., s. 19.

58 S. Grodziski, Prace nad kodyfikacja i unifikacja polskiego prawa prywatnego (1919-1947), KPP 1992, z. 1-4, s. 28; J. Skąpski, Kodeks cywilny z 1964 r. Blaski i cienie kodyfikacji oraz jej perspektywy, KPP 1992, z. $1-4$, s. 57.

59 A. Wolter, Prawo cywilne. Część ogólna, Warszawa 1977, s. 48.

60 W. Broniewski, Stowo o Stalinie, [w:] B. Urbankowski, Czerwona msza albo uśmiech Stalina, Warszawa 1995, s. 369. Stalinizacja kolonizowała wszelkie przejawy ludzkiej działalności. Wiersz W. Broniewskiego powstał w ramach konkursu z okazji 70-lecia urodzin Stalina. Do konkursu został on zaproszony przez samego Jakuba Bermana. Nastąpiło to w ostatniej chwili. Nawet J. Berman był bowiem wystraszony poziomem nadesłanych utworów. W. Broniewski wygrał, pokonując ówczesną elitę. B. Urbankowski, op. cit., s. 367. 


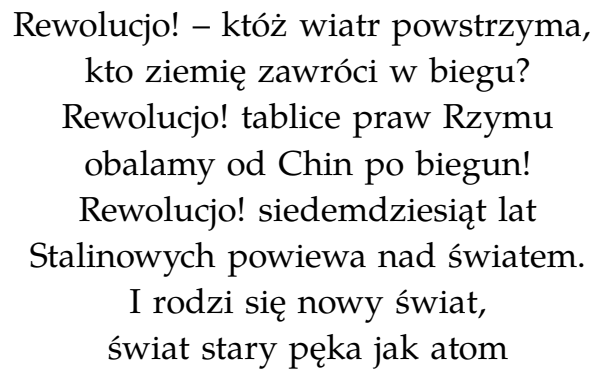

\section{Bibliografia}

\section{I. Źródła archiwalne}

1) Archiwum Akt Nowych, zespół akt: Ministerstwo Sprawiedliwości w Warszawie (2181, 2381).

2) Narodowe Archiwum Cyfrowe, Zespół nagrań dźwiękowych (Transmisja uroczystości poświęconej zakończeniu prac nad unifikacja prawa cywilnego w Polsce, odbywajacej się w gmachu Prezydium Rady Ministrów w Warszawie, 33-P-787).

\section{II. Źródła drukowane}

Broniewski W., Słowo o Stalinie, [w:] B. Urbankowski, Czerwona msza albo uśmiech Stalina, Warszawa 1995.

Chajn L., O właściwe rozeznanie. Na marginesie trzeciej rocznicy manifestu PKWN, DPP 1947, nr 7.

Czachórski W., Przebieg prac nad kodyfikacja prawa cywilnego PRL, „Studia Prawnicze” 1970, z. 26-27. Zeszyt specjalny wydany dla uczczenia pracy naukowej i kodyfikacyjnej Profesora Jana Wasilkowskiego.

Fiedorczyk P., O poczatkach prac nad kodyfikacja polskiego prawa cywilnego w 1947 r., MHI 2004, t. IV.

Fiedorczyk P., Dokumenty archiwalne dotyczace organizacji prac nad unifikacją i kodyfikacja polskiego prawa cywilnego w latach 1945-1948, MHI 2004, t. IV.

Górnicki L., Prawo cywilne w pracach Komisji Kodyfikacyjnej Rzeczypospolitej Polskiej w latach 1918-1939, Wrocław 2000.

Grodziski S., Prace nad kodyfikacja i unifikacja polskiego prawa prywatnego (1919-1947), KPP 1992, z. 1-4.

Gwiazdomorski J., Zarys prawa spadkowego, Warszawa 1961.

Kłos M., Wspólność majątku spadkowego, Warszawa 2004.

Kordasiewicz B., Testamentowe dziedziczenie gospodarstw rolnych, Warszawa 1978. 
Kordasiewicz B., Krag osób uprawnionych do zachowku, [w:] Księga jubileuszowa Profesora Tadeusza Smyczyńskiego, red. M. Andrzejewski i in., Torun 2008.

Kozioł A., Prace nad unifikacja prawa cywilnego w Polsce w latach 1945-1946 (Maszynopis rozprawy doktorskiej napisanej i obronionej na Wydziale Prawa i Administracji UŚ pod kierunkiem prof. A. Lityńskiego), Katowice 2006.

Księżak P., Zachowek w polskim prawie spadkowym, Warszawa 2010.

Kuryłowicz M., Krag spadkobierców ustawowych w ujęciu prawnohistorycznym, „Rejent” listopad 2006, nr 13.

Lityński A., Nowe ustawodawstwo w nowym ustroju. O prawie karnym i cywilnym w pierwszym dwudziestoleciu Polski Ludowej, MHI 2006, t. IV.

Lityński A., Historia prawa Polski Ludowej, Warszawa 2004, 2010.

Lityński A., Prawo Rosji i ZSRR 1917-1991 czyli historia wszechzwiązkowego komunistycznego prawa (bolszewików). Krótki kurs, Warszawa 2010.

Niedośpiał M., Testament w polskim prawie cywilnym - zagadnienia ogólne, Warszawa 1991.

Niezbecka E., Zapis, Lublin 1991.

Piątowski J. S., Prawo spadkowe. Zarys wykładu, Warszawa 1973.

Projekt prawa spadkowego. Tezy społeczno-polityczne, DPP 1946, nr 3.

Przybyłowski K., Rezerwa czy zachowek?, GSW z 22 maja 1939 r., nr 21.

Skąpski J., Kodeks cywilny z 1964 r. Blaski i cienie kodyfikacji oraz jej perspektywy, KPP 1992, z. 1-4.

Skowrońska E., Odpowiedzialność spadkobierców za długi spadkowe, Warszawa 1985.

Skowrońska E., Forma testamentu w prawie polskim, Warszawa 1991.

Szer S., Z zagadnień kodyfikacji prawa spadkowego, PiP 1951, z. 1.

Świątkowski H., Poznajmy prawo radzieckie, DPP 1948, nr 11.

Truszkiewicz Z., Zachowek ze spadku obejmujacego gospodarstwo rolne, Kraków 1993.

Trybulski Z., Bibliografia prawa cywilnego. Literatura, orzecznictwo 1945-1954, Warszawa 1956.

Wasilkowski J., Zagadnienie kodyfikacji jednolitego prawa cywilnego, DPP 1947, nr 1-2.

Wasilkowski J., Kodyfikacja prawa cywilnego w Polsce, NP 1950, nr 12.

Wierciński J., Brak świadomości albo swobody przy sporządzaniu testamentu, Warszawa 2010.

Witecki J., Odpowiedź na pytanie prawne, PiP 1949, nr 2.

Wolter A., Prawo cywilne. Część ogólna, Warszawa 1977.

Załucki M., Wydziedziczenie w prawie polskim na tle porównawczym, Warszawa 2010.

Z okazji zakończenia unifikacji prawa cywilnego (akademia), DPP 1947, nr 1-2. 